Article

\title{
Nurses' Recognition for Care for Patients in Psychiatric Wards
}

\author{
Michiyo Ando ${ }^{1, *}$, Hiroko Kukihara ${ }^{2}$, Haruka Kurihara ${ }^{1}$, \\ ${ }^{1}$ Faculty of Nursing, Daiichi University of Pharmacy, Fukuoka, Japan \\ ${ }^{2}$ Faculty of Nursing, Fukuoka University, Fukuoka, Japan \\ *Correspondence: m-ando@daiichi-cps.ac.jp. Tel.:+81-92-559-7331
}

\begin{abstract}
Coronavirus disease 2019 (COVID-19) has spread rapidly worldwide and it has been a widespread concern. Japan had some problems in psychiatric wards such as long hospital stay. The purpose of this study investigated recognition of nurses in psychiatric wards for future care. We conducted questionnaire research for psychiatric nurses and they described recognition of nursing in free description. Qualitative analysis was performed on description. Results showed that six categories were chosen like "Increase of stress and fatigue caused of infection control," "Negative effects to body and mind of patients," "Effects to nursing care in psychiatric nursing," "Differences of attitude toward infection control in the hospital," "Cognition for social movement related to Coronavirus," and "New awareness by Coronavirus infection and future." These results suggest the following, 1) some kind of supports will be needed for nurses' stress for infection control, 2) supports or interventions for palliate of patients stress like limitation of prolonged quarantine, limit of visiting or home stay overnight, 3) integrated leaderships to cognition and behavior for infection control in a hospital.
\end{abstract}

Keywords: COVID-19; Psychiatric Ward, Nurse, Recognition

How to cite this paper: Ando, M., Kukihara, H., \& Kurihara, H. (2021). Nurses' Recognition for Care for Patients in Psychiatric Wards. World Journal of Nursing Research, 1(1), 1-7. Retrieved from https://www.scipublications.com/journal/index.php/wjnr/article/view/103

Received: July 23, 2021

Accepted: August 26, 2021

Published: August 27, 2021

Copyright: (c) 2021 by the authors. Submitted for possible open access publication under the terms and conditions of the Creative Commons Attribution (CC BY) license (http://creativecommons.org/licenses /by/4.0/).

\section{Introduction}

Coronavirus disease 2019 (COVID-19) has spread rapidly worldwide, and it has been a widespread concern. It affects peoples' lives and their mental health. Health care workers are at high risk of COVID-19 infection. Shanafelt et al [1] showed the risk of anxiety and other negative mental health reactions among the workforce. Studies from China and Singapore showed the psychological impact of the current crisis [2] [3]. Worldwide, the COVID-19 was spread in several psychiatric hospitals. [4] [5]. In Japan, the number of infected patients are increasing in 2020 and 2021 year, and there have been some problems in psychiatric medicine such as the number of inpatients in hospitals compared to other countries. The ministry and Health Laver in Japan have recommend to discharge [6], however, patients' discharge and living in community is not progressing. In these situations, we focused on how nurses in psychiatric wards recognize nursing in the coronavirus woe.

\section{Materials and Methods}

The participants were 56 nurses in psychiatry wards in two hospitals in Western Japan (Table 1). We conducted a cross sectional questionnaire research. In the questionnaire, there were some quantitative psychological test and a qualitative question about the feeling in nursing in corona virus woe. "How do you feel or think in nursing in Coronavirus woe?" In this research we use "recognition" including feelings and thoughts. The researcher put the questionnaire in an envelope and passed them to a head nurse in two hospitals. A head nurse passed the questionnaire to nurses who could answer it. After 
about two weeks the researcher collected the questionnaire, and analyzed only the question as free description. This study was approved by the ethical board of Daiichi University of Pharmacy.

We conducted qualitative analysis by Tanizu [7] which involved creating codes, subcategories and categories. Free description were edited into the shortest statement without losing meanings as codes, and similar codes coded into subcategories and similar subcategories into categories. To maintain reliability, categorization and coding were validated independently by researchers. Inconsistencies were discussed and negotiated until an agreement was reached.

Table 1. Background of participants.

\begin{tabular}{cll}
\hline Item & \multicolumn{1}{c}{ Number } & Percentage (\%) \\
\hline \multirow{2}{*}{ Gender } & Male: 19 & 34 \\
& Female: $\quad 37$ & 66 \\
& 20 year: $: 6$ & 20 year : 11 \\
& 30 year: $\quad 7$ & 30 year: 13 \\
Age & 40 year: 29 & 40 year: 52 \\
& 50 year: 11 & 50 year: 20 \\
Experience year as a & 60 year: $\quad 3$ & 60 year: 5 \\
Nurse & \multicolumn{2}{c}{ Mean: 18.2} \\
\hline
\end{tabular}

\section{Results}

We chose codes, subcategories, and categories (Table 2). We showed a subcategory $<>$, and a category " " ".

Table 2. Categories about recognition for nursing in psychiatric wards

\begin{tabular}{|c|c|c|}
\hline Code & Subcategory & Category \\
\hline $\begin{array}{l}\text { We had difficulties such that the price of goods were high and we } \\
\text { couldn't use them as usual. }\end{array}$ & $\begin{array}{l}\text { 1) Stress from lack } \\
\text { of goods }\end{array}$ & $\begin{array}{l}\text { 1. Increase of stress } \\
\text { and fatigue } \\
\text { caused of infec- } \\
\text { tion control }\end{array}$ \\
\hline $\begin{array}{l}\text { - All staffs work on prevention infection. } \\
\text { - We worry about cluster occurrence. } \\
\text { - I felt difficulties and effort to behave with consciousness of } \\
\text { infection control. } \\
\text { - It is hard to prevent infection. }\end{array}$ & $\begin{array}{l}\text { 2) Difficulty of } \\
\text { infection control }\end{array}$ & \\
\hline $\begin{array}{l}\text { - Strengthening and limitation of infection prevention increases } \\
\text { stress. } \\
\text { - Not keeping up with the measures for prevention strength/fatigue, } \\
\text { - I felt fatigued by changing information. } \\
\text { - We tend to propose business instead of nursing. } \\
\text { - We were fatigued physically by coping with infection control. }\end{array}$ & $\begin{array}{l}\text { 3) Increase of stress } \\
\text { and fatigue }\end{array}$ & \\
\hline $\begin{array}{l}\text { - I am always anxious about bringing virus in the hospital. } \\
\text { - I pay attention to risk of bringing virus in. } \\
\text { - I pay attention to self-hygiene on a holiday. }\end{array}$ & $\begin{array}{l}\text { 4) Concerned about } \\
\text { infection in pri- } \\
\text { vate time }\end{array}$ & \\
\hline
\end{tabular}




\begin{tabular}{|c|c|c|}
\hline - I have been tired because I can't release stress on a holiday. & & \\
\hline $\begin{array}{l}\text { - Patients might feel crippled since they couldn't sleep at night. } \\
\text { - Continuation of infection prevention like mask or washing hands } \\
\text { may be a stress. } \\
\text { - Patients couldn't meet their families and friends. } \\
\text { - Patients live in hospital feeling crippled. }\end{array}$ & $\begin{array}{l}\text { 5) Stress of patients } \\
\text { due to limits in } \\
\text { hospitalized life }\end{array}$ & \multirow[t]{2}{*}{$\begin{array}{l}\text { 2. Negative effects } \\
\text { to body and } \\
\text { mind of patients }\end{array}$} \\
\hline $\begin{array}{l}\text { It seems to take much time to recover from their sickness because } \\
\text { of sense of obstruction in society. } \\
\text { - I feel that the health level of patients is lower than that of last year. } \\
\text { - I feel psychological distance between a patient and me. }\end{array}$ & $\begin{array}{l}\text { 6) Long-time } \\
\text { negative effects } \\
\text { to patients }\end{array}$ & \\
\hline $\begin{array}{l}\text { - Voice is hardly heard for elderly far from ear with masks. } \\
\text { - The other person's expression is hard to understand with mask. } \\
\text { - Patients and nurse have difficulty mutually communicating with } \\
\text { mask in psychiatric nursing. }\end{array}$ & $\begin{array}{l}\text { 7) Obstacle to com- } \\
\text { munication with } \\
\text { patients by mask }\end{array}$ & \multirow[t]{3}{*}{$\begin{array}{l}\text { 3. Effects to nursing } \\
\text { care in psychiat- } \\
\text { ric nursing }\end{array}$} \\
\hline $\begin{array}{l}\text { - Patients understand the states of Corona and we are grateful for } \\
\text { patients' understanding. } \\
\text { - It is hard for us to get understanding and cooperation from pa- } \\
\text { tients at chronic wards in psychiatry. } \\
\text { - I wonder if a patient with mental disease may follow a rule of not } \\
\text { leaving their room. } \\
\text { - It may be hard for us to get cooperation of infection prevention } \\
\text { countermeasures. }\end{array}$ & $\begin{array}{l}\text { 8) Differences by } \\
\text { degree of cooper- } \\
\text { ation depending } \\
\text { on comprehen- } \\
\text { sion }\end{array}$ & \\
\hline $\begin{array}{l}\text { - Moving to life after discharge is difficult because patients couldn't } \\
\text { have a chance of meeting face-to-face and had a sleepless night. } \\
\text { - Nurses had difficulty seeing how patients live at home because } \\
\text { they can't stay overnight. } \\
\text { - Patients couldn't or had a hard time to have relationships with } \\
\text { families. } \\
\text { - Nurses had a hard time to see relationships between a patient and } \\
\text { family members or support power. }\end{array}$ & $\begin{array}{l}\text { 9) Difficulty of dis- } \\
\text { charge support } \\
\text { because of being } \\
\text { hard to see fam- } \\
\text { ily relationships }\end{array}$ & \\
\hline $\begin{array}{l}\text { - Thinking or consciousness for infection improves whole hospitals. } \\
\text { - Nurses thought explanation about infection control does not con- } \\
\text { vey well to patients or staffs. } \\
\text { - Nurses couldn't perform unified measures, because there were } \\
\text { various ways of receiving explanation. } \\
\text { - Nurses have impression that adaptation to infection control of pa- } \\
\text { tients was better than that of staffs. }\end{array}$ & $\begin{array}{l}\text { 10) Differences of } \\
\text { cognition for in- } \\
\text { fection control } \\
\text { among staffs }\end{array}$ & \multirow[t]{2}{*}{$\begin{array}{l}\text { 4. Differences of } \\
\text { attitude toward } \\
\text { infection control } \\
\text { in the hospital }\end{array}$} \\
\hline $\begin{array}{l}\text { - Nurses felt difficulties for cooperation in a hospital to perform in- } \\
\text { fection control. } \\
\text { - There are differences of business burden in each department. } \\
\text { - Nurses had difficulties about getting understanding of infection } \\
\text { control by non-medical staffs. }\end{array}$ & $\begin{array}{l}\text { 11) Difficulties of } \\
\text { cooperation } \\
\text { with each de- } \\
\text { partment for } \\
\text { infection control }\end{array}$ & \\
\hline
\end{tabular}




\begin{tabular}{|c|c|c|}
\hline $\begin{array}{l}\text { Psychiatry nurses work such that they get in touch on mental } \\
\text { problems. } \\
\text { - There is a cultural climate such that nurses are conscious for other } \\
\text { staffs mutually and support each other. }\end{array}$ & $\begin{array}{l}\text { 12) Compassion of } \\
\text { psychiatric } \\
\text { nurses mutually }\end{array}$ & \\
\hline $\begin{array}{l}\text { - Nurses had difficulty to talk around people as medical staffs. } \\
\text { - Nurses felt sad that medical staffs disliked in nursery school in TV. }\end{array}$ & $\begin{array}{l}\text { 13) Prejudice to } \\
\text { health care } \\
\text { workers }\end{array}$ & \multirow{4}{*}{$\begin{array}{l}\text { 5. Cognition of so- } \\
\text { cial movement } \\
\text { related to Corona } \\
\text {-virus }\end{array}$} \\
\hline $\begin{array}{l}\text { - Nurses felt that people became irritable, since people around get } \\
\text { out when I sneeze with hay fever. } \\
\text { - I was often worried about visits and attendants in pediatrics. }\end{array}$ & $\begin{array}{l}\text { 14) Overreaction of } \\
\text { people to infec- } \\
\text { tion }\end{array}$ & \\
\hline $\begin{array}{l}\text { - Nurses felt that people get a new social rule like disinfection, mask } \\
\text { and temperature measurement. } \\
\text { - I think that it is better for people to get along with Coronavirus } \\
\text { without overreacting. } \\
\text { - I would like to get along with Coronavirus like any other illness. } \\
\text { - PR or enlightenment activities are needed for people to get along. }\end{array}$ & $\begin{array}{l}\text { 15) Necessity of } \\
\text { coping with } \\
\text { Coronavirus for } \\
\text { future }\end{array}$ & \\
\hline $\begin{array}{l}\text { - I felt unequal such that only accepting hospitals of Coronavirus } \\
\text { patients have great burden. } \\
\text { - Single department psychiatry didn't accept corona virus patients. } \\
\text { - Infection controls were different by hospitals. }\end{array}$ & $\begin{array}{l}\text { 16) Difference of ac- } \\
\text { cepting burden } \\
\text { or infection con- } \\
\text { trol in each hos- } \\
\text { pital }\end{array}$ & \\
\hline $\begin{array}{l}\text { - I felt that interaction with people was very precious. } \\
\text { - I became grateful for everyday life. }\end{array}$ & $\begin{array}{l}\text { 17) Awareness of } \\
\text { importance of } \\
\text { everyday life }\end{array}$ & \multirow[t]{3}{*}{$\begin{array}{l}\text { 6. New awareness } \\
\text { by Corona infec- } \\
\text { tion and future }\end{array}$} \\
\hline $\begin{array}{l}\text { I felt that infection prevention is important since there is not co- } \\
\text { rona virus patient. } \\
\text { - I recognize that protecting my health lead to protecting other peo- } \\
\text { ple who I am related to. } \\
\text { - To protect patients' and staff's safety is important, through requir- } \\
\text { ing changes in easier and harder parts. }\end{array}$ & $\begin{array}{l}\text { 18) Importance of } \\
\text { protection of } \\
\text { patients, staffs, } \\
\text { and myself from } \\
\text { infection }\end{array}$ & \\
\hline $\begin{array}{l}\text { I have to take leading role to improve knowledge and skills in } \\
\text { nursing. } \\
\text { Relax of nursing standards such that nurses in community can co- } \\
\text { operate in order to make up for the shortage of human resources. }\end{array}$ & $\begin{array}{l}\text { 19) Importance of } \\
\text { sending out in } \\
\text { formation for } \\
\text { social outreach } \\
\text { about medicine }\end{array}$ & \\
\hline
\end{tabular}

Nurses need many goods for infection control, however they couldn't use them as usual. They have to pay attention not only for patients with mental illness not to be infected, but also for themselves. So subcategories like 1) $<$ Stress from lack of goods $>, 2$ ) $<$ Difficulty of infection control $>, 3$ ) $<$ Increase of stress and fatigue $>$ and 4) $<$ Concerned about infection in private time $>$ were selected and integrated into a category $<$ Increase of stress and fatigue caused of infection control $>$.

Nurses felt influence of infection control to patients and nursing. Prolonged handwashing and mask, or limitation visiting and staying home overnight seemed to be great stresses. Subcategories like 5) <Stress of patients due to limits in hospitalized life $>6$ ) $<$ Long-time negative effects to patients $>$ were selected and integrated into a category 
"Negative effects to body and mind of patients." As for nursing to patients, mask or social distance seemed to be obstacles for communication. There are differences in ability to understand the new rule like social distance. Moreover, nurses couldn't get information of patients' family and relationships among them. Then subcategories like 7) $<$ Obstacle to communication with patients by mask $>, 8$ ) $<$ Differences by degree of cooperation depending on comprehension>, or 9) Difficulty of discharge support because of being hard to see family relationships $>$ were selected and integrated into a category "Effects to nursing care in psychiatric nursing."

There are various kinds of occupations in the hospital including medical staffs or non-medical staffs, and nurses felt differences of cognition among them. Also there were differences of cooperation in each department in the hospital for infection control. Although they felt these differences, they were considerate of each other. Then subcategories like 10) $<$ Differences of cognition for infection control among staffs $>, 11)<$ Differences of cooperation with each department for infection control $>$, or 12 ) $<$ Compassion of psychiatric nurses mutually $>$ were selected and integrated into "Differences of attitude for infection control in the hospital."

Also, nurses had cognition for social movement. Some nurses experienced prejudice in everyday life and felt overreaction for infection and need coping with corona virus for the future. They also felt that particular hospitals had the burden of accepting positive patients. In the present study, one is an accepting hospital and the other is not. Subcategories like 13) <Prejudice to health care workers $>$, 14) <Overreaction of people to infection $>, 15$ ) $<$ Necessity of coping with corona virus for future $>$, or 16) $<$ Difference of accepting burden or infection control in each hospital $>$ were integrated into "Cognition of social movement by Corona virus."

Lastly, nurses found new thinking of importance of everyday or families. They recognize the role of nurse for society. Subcategories like 17) <Awareness of importance of everyday life $>, 18$ ) <Importance of protection of patients, staff and myself from infection>, or 19) <Importance of sending our information for social outreach about medicine $>$ were selected and integrated into "New awareness by Corona infection and future."

\section{Discussion}

\section{1) Increase of stress and fatigue caused of infection control}

Nurses worried about cluster occurs and tried to prevent infection. Nurses felt insufficiency of goods in treatment and worked for infection control. These nurses' stress supports previous studies. In a Chinese explanatory study, the psychological problems of health care workers, especially women, nurses with low educational background, low professional title, and staff in the epidemic prevention and control positions are relatively serious [8]. Another study showed that a considerable proportion reported the need for professional guidance from psychologists and more support from their leadership [9]. Also, flexible working hours and the utilization of psychosocial and psychological help without stigmatization seem to be important measures [10]. Support from organization system like goods or leaderships and psychological care will be needed.

\section{2) Influence of nursing in psychiatry wards}

Patients felt $<$ Stress due to limits in hospitalized life $>$. Prolonged wash hands and mask and various limitations are great stresses for patients. Patients with mental disorder have some symptoms and are not so stable, these limitation might force their stress. It supports Brooks et al. [11] that patients were likely to experience anger and frustration due to quarantine, and Iasvoli et al. [12] that patients perceive a higher level of distress due to the prolonged quarantine than that perceived by the general population. Some kind of palliation of patients' stress will be needed. 
Nurses felt $<$ Obstacle to communication with patients with mask $>$. In mental health nursing, a patient is cured through therapeutic communication. It is difficult for a patient to see facial expression of nurses and hard to hear from nurses by mask. Some patients with mental disorder can't express well their intention, non-verbal communication is very important. Gao, et al [13] said that therapeutic interaction between nurses and patients is essential. Mask or full PPE (personal protective equipment) may be an obstacle to communication. Some kind of ingenuity to understand facial expression and promote communication will be needed.

About $<$ Difficulty of discharge support because of being hard to see family relationships $>$, nurses had difficulty seeing how patients live at home. As shown in the introduction section, long-time hospitalization was a serious problem. By the influence of Coronavirus, adjustments for discharge may be difficult and the discharge is postponed, resulting in long-term hospitalization. In these days, there are some techniques of connecting patients and family members like Zoom, nurses can use these techniques for progress of support of discharge.

\section{3) Organizational policy and future}

As for hospital organization, nurses in the present study had difficulties of cognition for infection control among staffs or difficulties of cooperation with each department for infection control. Gao et al. [13] showed that prompt and effective contingency planning and policy making at the national and institutional level, targeting human resource management and infection control, can introduce changes and alternative options for nursing care in a pandemic. Integrated leadership will be needed. Lastly nurses found new recognition such as importance of daily life or people around them, these findings support Okabayashi [14] such that nurses found dilemma in that a greater weight is placed on them rather than patient care and got opportunity to consider the nursing that they perform. It may be important to look back on their nursing, and progress for the future.

\section{Conclusions}

Nurses in a psychiatric ward felt stress for infection control, influence for nursing for patients like obstacle of communication, interpersonal care, and delay of discharge. They need to cope with these problems for the future.

\section{Patents}

There is no patent.

\section{Author Contributions:}

MA: Conceptualization, investigation, data analysis

$\mathrm{HaK}$ : Investigation, data analysis

HiK: Conceptualization, investigation

All authors read paper and confirmed submission.

\section{Funding:}

\section{Data Availability Statement:}

MA have data and managed.

Acknowledgments: We are deeply grateful to the nurses who participated in this research.

Conflicts of Interest: There is no conflict of interest. 


\section{References}

[1] Shanafelt T, Ripp J, Trockel M. Understanding and addressing sources of anxiety among health care professionals during the COVID-19 pandemic. JAMA, 2020, 323(21), 2133-2134. https://doi:10.1001/jama.2020.5893

[2] Kang L, Ma S, Chen M, et al. Impact on mental health and perceptions of psychological care among medical and nursing staff in Wuhan during the 2019 novel coronavirus disease outbreak: a cross sectional study. Brain Behav Immun, 2020, 87, 11-17.

[3] Tan BYQ, Chew NWS, Lee GKH, et al. Psychological impact of the COVID-19 pandemic on health care workers in Singapore. Ann Intern Med, 2020, 173(4). https://doi:10.7326/M20-1083

[4] Ramgopal K. Coronavirus in a psychiatric hospital: "It's the worst of all worlds" NBC new, 18 April. https://www.nbcnews.com/health/,ema;-health/coronavirus-psychiatric-hospital-ot-s-worst-world-n 1184266 (accessed 7 August, 2021)

[5] Yao H, Chen JH. \& Xu YF. Patients with mental health disorders in the COVID-19 Epidemic. The Lancet Psychiatry, 7, E21. https://doi.org/10.1016/s2215-0366(20)300090-0

[6] Ministry Health Labor and Welfare, Seishinsyogainimotekioushita chiikihoukatsukeashisutemuno kochikunitsuite (About Construction of community-based comprehensive care system corresponding to the mentally handicapped) https://www.mhlw.go.jp/stf/seisakunitsuite/bunya/chiikihoukatsu.html (accessed 7 August, 2021)

[7] Tanizu Y. Start up Shitsutekikangokenkyu [Qualitative Nursing Research] $2^{\text {nd }}$ Edition, Gakken Medical Yujunsya. Tokyo, 2015.

[8] Fang, Xue-H, Wu L, Lu LS, et al. Mental heal problems and social supports in the COVID-19 health care workers: a Chinese explanatory study. BMC Psychiatry, 2021, 21, 34. https://doi.org/10.1186/s12888-020-02998-y

[9] Vanhaeche K, Seys, D, Bruyneel L, et al. COVID-19 is having a destructive impact on health-care workers' mental wellbeing. Int J Qual Health Care, 2020 Dec3: mzaa158. https://doi:10.1093/intqhc/mzaa158

[10] Petzold MB, Plag J, Strohle, A. Dealing with psychological distress by healthcare professionals during the COVID-19 pandemia. Nervenarzt, 2020 May, 91(5), 417-421. https://doi:10.1007/a00115-020-00905-0

[11] Brooks SK, et al. The psychological impact of quarantine and how to reduce it: rapid review of the Evidence. The Lancet, 395(10227), 839-920. https://doi.org/10.1016/S0140-6736(20)30460-8

[12] Iasevoli F, Fornaro M, D'Usro G, t al. Psychological distress in serious mental illness patients during the COVID-19 out break and on-monghe mass quarantine in Italy. Psycholog Med, 50(7), 1-3. https://doi.org/10.1017/s003329172000184

[13] Gao Z, Tan FPL. Nurses' experiences in response to Covid-19 in a psychiatric ward in Singapore. Int Nurs Rev, 68-196-201.

[14] Okabayashi, S. Feelings and thoughts of nurses who nursed COVID-19 patients and how they dealt with it. J Kochi Med Associ, 26(1), 104-110. 